\title{
On the Real Nature of the Tracheae in the Ferns.
}

\author{
BY
}

\author{
D. T. GWYNNE-VAUGHAN, M.A., F.L.S., \\ Lecturer in Botany at Birkbeck College, London.
}

\section{With Plate XXVIII.}

$\prod$

$\mathrm{HE}$ following observations were originated by an investigation recently carried on by Dr. Kidston and myself into the structure of certain fossil Osmundaceae. ${ }^{1}$ In some of the specimens that were examined the preservation of the xylem was unusually good, and much information was obtained concerning the detailed structure of the tracheal walls. It was found, however, that our observations on the fossils could not be brought into agreement with the prevalent idea of the structure of a Fern tracheide. This necessitated a re-examination of the xylem of some of the recent Ferns in order to see if this difficulty could not be explained away, eventually leading to the following unexpected conclusions :-

In the first place, it may be stated that the metaxylem of the Filicales is generally regarded as consisting, for the most part, of typical scalariform tracheides; the typical scalariform tracheide possessing a single series of pits on each of its sides or facets. Very few exceptions to this statement have as yet been recorded. The 'tracheide' type of element is known to be departed from in two cases only: Pteris aquilina and Nephrodium filix-mas (in the root). In these it is stated that true perforations occur in the end walls of the tracheae, which must, therefore, be regarded as vessels. ${ }^{2}$ As regards the kind of pitting, it is known that more than one series of pits occur constantly on the same facet in the xylem elements of Botrychium, ${ }^{3}$ Helminthostachys, ${ }^{4}$ and in certain Botryopterideae.

${ }^{1}$ Kidston and Gwynne-Vaughan, ' On the Fossil Osmundaceae,' parts i and ii, Trans. Roy. Soc. Edin., vol. xlv, part iii, p. 759, 1907, and vol. xvi, part ii, 1908.

2 Russow, 'Vergleichende Untersuchungen,' Mém. de l'Acad. Imp. des Sc. de Saint-Pétersb., Bd. xix, p. $103,187^{2}$.

${ }^{3}$ Idem, p. I 8 .

' Farmer and Freeman, 'Affinities of Helminthostachys zeylanica,' Annals of Botany, vol. xiii, p. 433,1899 .

[Annals of Botany, Vol. XXIII. No. LXXXVII. July, 1908.] 
It appears from our observations that the above statement is thoroughly misleading, and that a return must be made to the views held by the earlier anatomists, ${ }^{1}$ who believed that the xylem elements of the Ferns in general were true vessels and not tracheides at all.

The xylem of the Osmundaceae will first be described, and in particular that of Osmunda cinnamomea, in which plant the point in question was the most thoroughly investigated. To begin with, it appears that the Osmundaceae as a whole must be added to the list of Ferns whose tracheae constantly possess more than one vertical series of pits on each side of their walls. Almost all the sides or facets have two or more series of pits (P1. XXVIII, Fig. I) ; indeed, the typical scalariform marking with a single series of pits is only to be found on the smallest elements at the external periphery of the xylem ring and on those of the decurrent protoxylem strands of the leaf-trace. In the fossil representatives of the order the multiseriate nature of the pitting is even more pronounced, walls being often found with as many as four or five regular series. In the largest elements the pits are so numerous, and so irregularly arranged, that in surface-view the walls present the same reticulate or porose appearance as do the xylem elements of Botryopteris (Fig. 2).

To turn now to the actual nature of the pits themselves; it soon became clear that there is no pit-membrane whatever separating the cavities of two contiguous tracheae from one another. The pits are, in fact, actual perforations permitting free lateral passage through the side walls of the tracheae. This is not all, for the repeatedly unsuccessful attempts to demonstrate a pit-membrane gradually brought to light the surprising fact that there was no 'middle substance' in the other parts of the wall; not even between the bars of thickening that separate the pits. For instance, in a wall bearing a single series of pits the bars of thickening stretch across quite freely from one corner to another without coming into contact in the median plane of the wall (Fig. 3). The bars are in opposite pairs, one belonging to each of the two contiguous tracheae, and there is an empty space between them. It follows, therefore, that there is a free passage both up and down in the middle of the common wall from one pit cavity to the other throughout the whole series of pits. When there is more than one series of pits on the same side of the wall, matters are not quite so simple, for the parts of the wall separating the several series of pits vertically are solid right through (Fig. 4). At these points the bars belonging to the two tracheae are firmly cemented together by an intervening 'middle substance.' In this case, therefore, although there is the same free passage up and down in the middle of the wall for each series of pits, there is no direct lateral passage from one vertical series to the other.

${ }_{1}$ Dippel, Das Mikroskop (new ed.), p. 280 (Ist ed. 1869); Sachs, Textbook of Botany (English ed.), pp. 25-26; Gustav A. Weiss, Anatomie der Pflanzen, p. 271 , I878. 
I was able to satisfy myself that these holes are real and normal and are not due to any accident or preservation, because they can be observed in sections taken from fresh and living material. They are, of course, exceedingly narrow, but at the same time they are distinctly visible under a Zeiss D objective in stained sections of sufficient thinness.

The actual formation of these holes can be followed in sections cut at different levels just below the meristem of the apex, in a region where the xylem is still more or less imperfectly lignified. The sections should be treated with some dye that has an affinity for the pectic substances of which the young cell-walls are chiefly composed. The best results were obtained with ruthenium red; a dye especially recommended for this purpose by Mangin ${ }^{1}$ and used with success by Allen in his work on the middle lamella. ${ }^{2}$ It is made up in watery solution; about $.02 \mathrm{gr}$. of the dye to 100 c.c. of water. The solution should then be rendered alkaline by the addition of about 5 c.c. of concentrated ammonia. It should be kept in a blackened bottle, for it is gradually decomposed by the action of light. In any case, its action becomes much less intense if kept for over a month. Sections stained by ruthenium red can be brought up into Canada balsam. Allen states that the stain gradually fades away, but after several months my preparations hardly show any deterioration. A very pretty effect may be obtained by counterstaining with methylene blue, which has an affinity for lignin. Partly lignified walls show gradations in the intensity of the blue stain. Pectic substances also stain well with methanil violet and Hoffman's violet.

When a transverse section of a partially differentiated xylem strand is treated with ruthenium red, the primary walls of the youngest tracheae are stained a deep red. The dye is taken up by the whole thickness of the wall, but at the same time an extremely thin middle lamella is just perceptible as a very fine line more deeply stained than the rest. The primary wall remains comparatively thin except at the angles, which later on become especially thickened (Fig. 5). These angular thickenings stain somewhat differently to the rest of the wall, although they still give a pectic reaction. In a slightly older wall the thick secondary layers will have been deposited on the thin primary wall, over all its surface except those regions destined to become pits. When first deposited these secondary layers also consist of pectic substances and take up the stain almost as readily as do the primary walls (Figs. 6 and 7). At this stage a fair amount of protoplasm is still present in the young trachea, but the nucleus seems to disappear during the deposition of the secondary layers or even earlier. Longitudinal

1 Mangin, 'Sur l'emploi du rouge de ruthénium en anatomie végétale,' Comptes-Rendus de l'Acad. des Sc. Nat. de France, t. I16, p. 653, 1893.

' Allen, 'On the Origin and Structure of the Middle Lamella,' Bot. Gaz., vol. xxxii, No. I, p. I, I90I. 
sections indicate that the tracheae undergo a considerable amount of sliding growth which must take place while they are still in a thin-walled condition. The first signs of lignification in the secondary layers appear at the corners. Shortly afterwards they become lignified all over, and so do the angular thickenings of the primary walls (Figs. 6 and 7, unshaded), and also the regions separating the vertical series of pits. All the rest of the primary wall remains pectose, and as soon as the lignification of the above-mentioned regions is completed it begins to show signs of disintegration. Its substance breaks up and becomes granular and then gradually disappears without, however, altering its composition, for to the last it is coloured by the pectic stains (Fig. 8). Its complete re-absorption leaves an empty space between the two bars of secondary thickening, or, in the region of a pit, sets the cavities of the two contiguous tracheae into continuity. The pectose portions of the primary wall seem to be reabsorbed more rapidly in some specimens than in others, and in all cases some remains are still to be observed coating the extremities of the persistent lignified parts (Figs. 3 and 4). Where a trachea borders upon a cell of parenchyma the primary wall of the trachea remains intact, and so also does the middle lamella between it and the wall of the parenchymatous cell. It follows from this description that the holes in the tracheal walls are due to the re-absorption of the whole thickness of the primary wall of the young tracheae at the points in question, and not merely to the disappearance of the middle lamella.

Longitudinal sections are not particularly helpful in demonstrating these holes. To obtain an ideal section the razor should pass twice through the same series of pits and then the several bars, being loose and unconnected, all fall away from one another. In thicker sections the pectic remains that coat the ends of the persistent portions of the primary wall are visible through the unstained lignified parts and simulate a continuous middle substance. If however, the cut edge of a vertical wall be brought into focus it is seen that the pits are extremely narrow, and that the bars of thickening often vary greatly in width. They usually project much further into the cavity of the element in the neighbourhood of the corners than elsewhere. This accounts for the overlapping outlines so often seen in transverse section (Fig. 8).

The same type of element was found in stem, leaf, and root of all the species of Osmunda and Todea that were examined, and it may also be confidently inferred in the fossil representatives of the order. A reference to Fig. II, which is a photograph of the xylem of Osmundites skidegatensis will illustrate the peculiar and at first inexplicable appearance of the tracheal walls that initiated these observations. It now appears obvious that the black bars represent the bars of thickening, while the white spaces represent holes that occur in the substance of the walls. In the other fossil members of the order the xylem-walls vary very much in appearance 
according to the nature of the preservation, but in all cases they may be readily brought into agreement with the type of element described above, except the largest tracheae, which possess irregularly scattered more or less rounded pits. In these it is probable that each pit is an isolated perforation whose cavity does not communicate with those of the others.

It is no longer possible, therefore, to regard the xylem elements of the Osmundaceae as tracheides; on the contrary, they are a special and very peculiar type of vessel. In each separate xylem mass of the stele there is a perfectly free passage for water in all directions from one element to another both vertically and horizontally; to say nothing of the passages that occur in the very substance of the walls.

In order to obtain some real genuine tracheides for the purpose of checking the observations made upon the xylem of the Osmundaceae, I next examined that of Nephrodium Filix-mas. In this plant the xylem elements are typically scalariform, with one series of pits only on each side of the wall. But here also it was found that the primary wall is completely re-absorbed both in the region of the pits and between the bars of secondary thickening (Fig. 9). In fact, they have no right whatever to be called tracheides, but are vessels of the same type as those of the Osmundaceae, the only difference being that they are typically scalariform.

Pteris aquilina was next tried, and here a somewhat different type of element was met with, although still undoubtedly a vessel and not a tracheide. They are typically scalariform, and here again the pits, both on the end walls and on the side walls, are true perforations. They differ, however, from the vessels of the Osmundaceae and of Nephrodium, in that those parts of the primary wall that connect the opposite transverse bars of secondary thickening in the middle of the wall are here maintained intact even at maturity. The bars of each pair are, therefore, joined together by a cementing substance across the thickness of the wall. These persistent parts of the primary wall do not become lignified, but remain pectic in character and stain readily with ruthenium red. When a tracheal wall treated with this reagent is regarded in surface view, the pectic middle substance will appear as a red area shining through the lignified and unstained secondary layers and outlining the inner limits of the pit cavities as shown in Fig. IO. The shaded regions represent the pectic cementing substance connecting the bars in the middle of the wall, and it is seen that the widest extension of the pits greatly exceeds their apertures into the lumen of the vessel.

Sachs in 1874 was already aware that the xylem elements of Pteris aquilina bore true perforations on their lateral walls. The figures he gives in his textbook (1.c. Fig. 27) illustrate most clearly and accurately the actual state of affairs. On the other hand, they escaped the notice of De Bary, Strasburger, and subsequent observers. Very probably this was 
due to a natural tendency to cut as near to the apex as possible in order to avoid the inconvenience caused by the mature sclerenchyma. The tracheae in such regions would be too young for the complete disappearance of the primary wall.

Vessels of the Pteris type seem to be very widely distributed among the Pteridophyta. They were observed in the Polypodiaceae, Cyatheaceae, Hymenophyllaceae, Gleicheniaceae, Schizeaceae, Marattiaceae, Ophioglossaceae, Lycopodiaceae, and in the fossils Psaronius, Botryopteris, and Zygopteris. With regard to Zygopteris, Professor Weiss has pointed out to me that the presence of open passages in the side walls of the tracheae renders it easy to account for the thyloses he found far away from any living elements in the most central tracheae of the non-parenchymatous xylem mass. ${ }^{1}$

As a matter of fact, true and indisputably imperforate tracheides were not met, with in any one of the Pteridophyta examined. These were, however, far too few to permit any generalization. On the contrary, true tracheides must occur in the Calamites at any rate, for it appears that vertical striations can be observed on their pit-membranes.

Even in the Gymnosperms the true tracheide is by no means so general a type as might be supposed. From some preliminary preparations made by Miss S. Greves that I have been permitted to examine, it appears that true perforations occur in the longitudinal walls both in the primary and secondary xylem of some of the Cycads. This is probably the case also in the secondary wood of Araucaria; at any rate, it has not been found possible to demonstrate a pit-membrane there.

Considered from a mechanical point of view, elements of the Osmundaceous type would appear to be very unsuitable for conferring strength and rigidity to the xylem as a whole. The fact that in the Ferns as a whole, and particularly in the Osmundaceae, the function of support is taken over almost entirely by masses of strong sclerenchyma in the ground tissue, has perhaps rendered the existence of this type of vessel possible. Even under these conditions it seems that mechanical exigencies prevent the width of the tracheal wall exceeding a certain limit. In the Osmundaceae the limit of width for a wall with a single series of pits is about $45 \mu$. Walls of greater width have the bars cemented together about half-way across, so that there are two series of pits, and may attain as much as $70 \mu$. With three series of pits they reach $90 \mu$, and with four up to $104 \mu$. In Nephrodium Filix-mas, walls with a single series were found as much as $55 \mu$ wide. Of course, when each pair of bars is cemented together along the whole width of the wall, as in Pteris aquilina, the mechanical efficiency is greatly increased and walls with a single series of pits may be as wide as $130 \mu$.

${ }^{1}$ F. E. Weiss, 'On the Thyloses of Rachiopteris corrugata', New Phyt., vol. iv, No. 4, p. $82,1906$. 
As regards the pattern of the pitting, I am inclined to regard rounded pits as more primitive than scalariform. The rounded pits would be at first irregularly distributed, and their subsequent arrangement in regular vertical series would prepare the way for an advance towards the multiseriate vessel of the Osmundaceous type. The typical scalariform pattern may have been derived from the multiseriate type, but not necessarily so. It may equally well have arisen by the approximation and transverse elongation of a single series of rounded pits. A single series of more or less rounded and very irregularly scattered pits is still to be met with in the xylem of Botrychium and Helminthostachys.

\section{SUMMARY.}

The xylem elements of the Pteridophyta are, for the most part, vessels with true perforations in their longitudinal as well as in their terminal walls.

In the Osmundaceae, Nephrodium Filix-mas, and probably others, a special type of vessel occurs which is characterized by the complete disappearance of the primary tracheal wall at certain points, so that the cavities of the pits are vertically continuous in the middle of the wall.

It is probable that more or less rounded pits preceded the transversely elongated pits of the scalariform type in the Filicales.

\section{DESCRIPTION OF FIGURES IN PLATE XXVIII.}

Illustrating Mr. Gwynne-Vaughan's paper on Tracheae in the Ferns.

Figs. 1, 2, and II are photographs, the rest are drawings.

Fig. I. Osmunda cinnamomea. Wall of vessel with three regular series of pits in surface view.

Fig. 2. Zalesskya gracilis. Wall of vessel with porose pitting in surface view.

Fig. 3. Osmunda cinnamomea. Transverse section of a wall with a single series of pits.

Fig. 4. Osmunda cinnamomea. Transverse section of a wall with three series of pits.

Fig. 5. Osmunda cinnamomea. Transverse section of some very young xylem elements. The primary wall alone is formed and it is especially thick at the corners.

Figs. 6 and 7. Osmunda cinnamomea. Transverse section of some older xylem elements. The layers of secondary thickening have been deposited on the pectose primary wall. In some the secondary layers are lignified (lightly shaded), in others they are still partly pectose (darker shading) and protoplasm is still present. Note that the lignification commences at the corners, and also that the primary wall also lignifies at these points.

Fig. 8. Osmunda cinnamomea. Transverse section of still older elements. All the secondary elements are now lignified, and so are the corner-pieces of the primary wall. Other regions of the primary wall are being re-absorbed, leaving empty spaces in the middle of the wall.

Fig. 9. Nephrodium Filix-mas. Transverse section of the mature xylem. The walls only bear one series of pits. The cells on the left are xylem parenchyma.

Fig. 10. Pteris aquilina. Wall of a vessel in surface view. The shaded regions indicate the parts of the pectose primary wall that persist and cement the bars together.

Fig. I1. Osmundites skidegatensis. Transverse section of the xylem. 

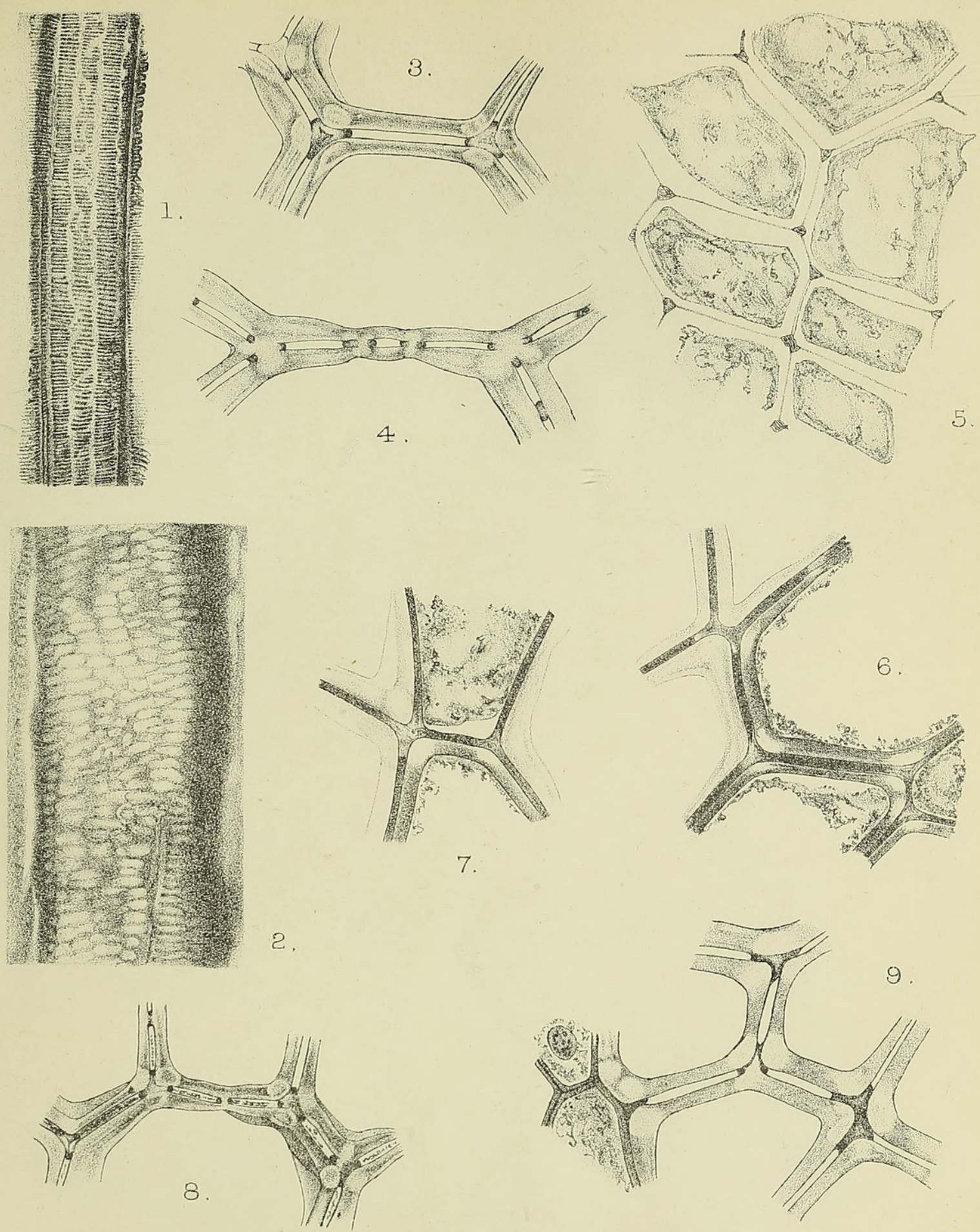

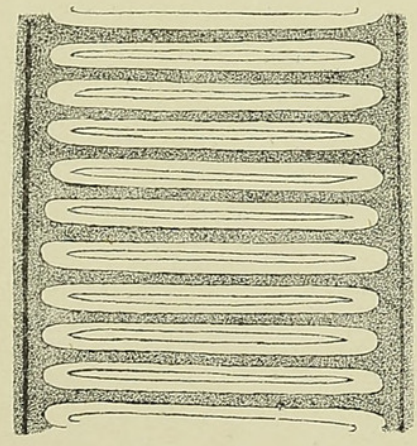

10.

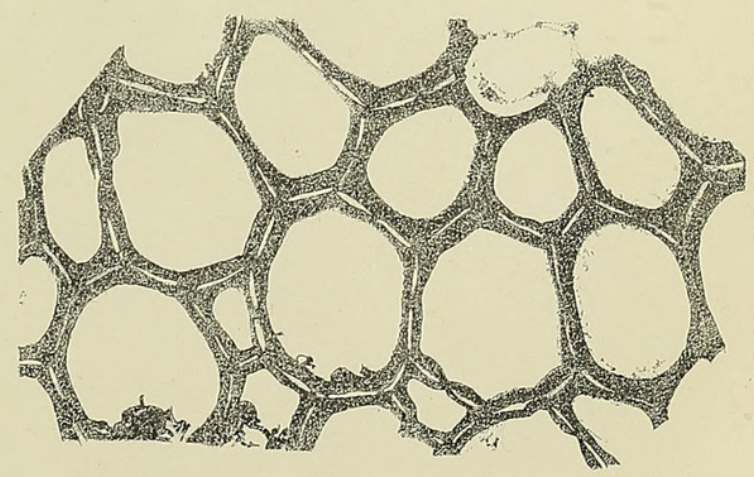

11. 


\section{$2 \mathrm{BHL}$ Biodiversity Heritage Library}

Gwynne-Vaughan, D. T. 1908. "On the real nature of the tracheae in the ferns." Annals of botany 22, 517-523.

https://doi.org/10.1093/oxfordjournals.aob.a089186.

View This Item Online: https://www.biodiversitylibrary.org/item/232525

DOI: https://doi.org/10.1093/oxfordjournals.aob.a089186

Permalink: https://www.biodiversitylibrary.org/partpdf/318922

\section{Holding Institution}

Smithsonian Libraries

\section{Sponsored by}

Biodiversity Heritage Library

\section{Copyright \& Reuse}

Copyright Status: Not in copyright. The BHL knows of no copyright restrictions on this item.

This document was created from content at the Biodiversity Heritage Library, the world's largest open access digital library for biodiversity literature and archives. Visit BHL at https://www.biodiversitylibrary.org. 